\title{
ANALYSING THE DEMAND FOR FINANCIAL ASSETS IN INDONESIA
}

\author{
Eliyathamby A Selvanathan ${ }^{1}$, Saroja Selvanathan ${ }^{2}$ \\ ${ }^{1}$ Economics and Business Statistics Discipline, Griffith Business School, Griffith University, \\ Queensland, Australia. \\ ${ }^{2}$ Economics and Business Statistics Discipline, Griffith Business School, Griffith University, \\ Queensland, Australia. Email: s.selvanathan@griffith.edu.au
}

\begin{abstract}
This paper analyses the demand for three important financial assets (i.e. bank deposits) in Indonesia: demand deposits, saving deposits, and time deposits. We use a systemwide approach to consumption economics to perform the analysis in the long and short run. The estimation results reveal that a) generally, the wealth elasticity for saving deposits is above one, for time deposits is below one, and for demand deposits it varies from 0.5 (in the short run) to 1.1 (in the long run); b) the own interest rate coefficients are statistically significant and positive, as expected; and c) in the long run, while the assets of demand deposits and time deposits and of saving deposits and time deposits are pairwise substitutes, the assets of demand deposits and saving deposits are pairwise complements.
\end{abstract}

Keywords: Financial assets; Demand deposits; Saving deposits; Time deposits; Wealth elasticity; Interest rate.

JEL Classifications: G11; G21.

Article history:

Received : November 9, 2018

Revised : : December 31, 2018

Accepted : : March 21, 2018

Available online : April 30, 2019

https://doi.org/ 10.21098/bemp.v22i1.982 


\section{INTRODUCTION}

Financial assets such as bonds, certificates, stocks, and bank deposits are considered intangible assets. Investors shift their investments regularly from one asset to another. For example, when interest rates on deposits increase, the stock market is impacted, since investors in the stock market are more likely to deposit funds in commercial banks. Therefore, an understanding of consumer behaviour in the context of financial assets is important to macroeconomic policymakers in the government and the banking industry. For example, to determine the desired interest rate of a particular bank deposit, bank managers need to know the level of substitutability/complementarity between that bank deposit and other financial assets, including other bank deposits.

The focus of this paper is on only one type of financial asset, namely, bank deposits. We choose bank deposits because they play an important role in the economy via bank loan investment channels. Because we examine three types of bank deposits - demand deposits, saving deposits, and time deposits - we consider our analysis a conditional analysis within the larger financial assets group.

Brainard and Tobin (1968) introduced work on modelling consumer demand for different types of financial assets based on the multivariate stock adjustment model. The disadvantage of using this model is that large number of parameters must be estimated. Later, Taylor and Clements (1983) used a system-wide approach, which has the advantage of requiring the estimation of fewer parameters by testing and imposing certain restrictions based on economic theory. In recent years, a number of papers analysing various issues in relation to financial assets have been published (e.g. Brainard and Tobin 1968; Motley, 1970; Dalal, 1983; Taylor and Clements, 1983; Callen and Thimann, 1997; Juster et al., 2006; Narayan et al., 2009; Carroll et al., 2011; Arrondel et al., 2013; Heykal et al., 2014; Kukk, 2014; Jha, 2015; Becker and Dimpfl, 2016). However, no empirical research is available that analyses the demand for financial wealth in Indonesia. This study aims to fill that gap.

Bank deposits play an important role in the Indonesian economy. Bank deposits as a percentage of the gross domestic product in Indonesia steadily increased from $8.2 \%$ in 1982 to $42.3 \%$ in 1998 , steadily decreased to $29.5 \%$ by 2008 , and then started to increase again, reaching 33.7\% in 2015. Generally, the banking industry raises funds from the public and delivers it back to the community, especially in the form of loans to businesses, and such investments lead to greater production, employment, and export opportunities in the economy. Indonesia is no exception. For example, a recent World Bank (2010, Ch. 2) report states that the number of bank branches in Indonesia increased by 70\% from 2000 to 2010 and the number of ATMs trebled, which has had a positive influence in remote parts of the country and increased the intermediation of inputs (deposits) into outputs (loans), benefitting the Indonesian economy. Therefore, a comprehensive analysis of the demand for bank deposits is crucial for policymaking in the banking industry and the Indonesian government in general.

This paper attempts to answer a number of research questions, such as the following: 1) Are wealth and the interest rates for demand deposits, saving deposits, and time deposits in Indonesia elastic or inelastic? 2) Are there any differences in the wealth and interest rate elasticities for bank deposits in the short and long run? 
3) Is there any substitutability or complementarity between the three types of bank deposits?

We perform a conditional analysis using a system-wide framework to answer these research questions in relation to the demand for three important financial assets in Indonesia: demand deposits, saving deposits, and time deposits. We estimate the wealth elasticities and interest rate elasticities of these three financial assets and determine the levels of substitutability/complementarity between them in the short run and the long run.

This paper is organized as follows. Section II presents the demand models for financial assets. Section III describes the data. Short- and long-run estimation results for Indonesian financial assets are presented in Section IV. Concluding comments are made in Section V.

\section{DEMAND MODEL FOR FINANCIAL ASSETS}

Let $A_{\mathrm{i}}$ be the nominal value of a financial asset $i=1,2, \ldots, n$ and $n$ be the number of assets. Let $a_{i}=A_{i} / C P I$ be the corresponding real value of financial asset $i$, where $\mathrm{CPI}$ is the consumer price index. Let $W=\sum_{i=1}^{n} a_{i}$ be total real wealth and $r_{i}$ the interest rate on asset $i$. We can now set up investors' decision making process as maximizing real interest earnings, $R=\sum_{i=1}^{n} r_{i} a_{i^{\prime}}$ subject to transactions technology, where the transactions of assets are determined as a function of total wealth, $f\left(a_{i}, a_{2}, \ldots, a_{n}\right)=g(W)$ with $\mathrm{\partial} f / \partial a_{i}>0,\left[\partial^{2} f / \partial a_{i} \partial a_{j}\right]$ a symmetric positive definite matrix of order $n \times n$, and $g(W)>0$. That is, the investor's decision making process can be written as

$$
\operatorname{Max} R=\sum_{j=1}^{n} r_{i} a_{i}
$$

subject to

$$
f\left(a_{1}, a_{2}, \ldots, a_{n}\right)=g(W)
$$

The Lagrangian function for this maximization problem can be written as

$$
R^{*}=\sum_{i=1}^{n} r_{i} a_{i}+\left[f\left(a_{1}, a_{2}, \ldots, a_{n}\right)-g(W)\right]
$$

If we write $\mathrm{a}=\left[a_{i}\right]$ and $r=\left[r_{i}\right]$, then we can write equation (2) in vector form as

$$
R^{*}=r^{\prime} a+\lambda[f(a)-g(W)]
$$

The first-order conditions of the maximization of $R^{*}$ are

$$
\frac{\partial R^{*}}{\partial a}=r-\lambda \frac{\partial f}{\partial a}=0
$$

and

$$
\frac{\partial R^{*}}{\partial \lambda}=[f(a)-g(W)]=0
$$


that is,

$$
r=\lambda \frac{\partial F}{\partial a} \text { and }[f(a)-g(W)]=0
$$

Solutions to (4) will result in a demand equation for asset $i$ of the form

$$
a_{i}=a_{i}\left(W, r_{i}, r_{2}, \ldots, r_{n}\right)
$$

\section{A. Long-run demand system}

Let $s_{i}=a_{i} / W$ be the portfolio share of asset $i$. We propose the demand equation for asset $i$ takes the form

$$
s_{i}=\alpha_{i}+\beta_{i} \log W+\sum_{j=1}^{n} \pi_{i j} r_{j}, \quad i=1, \ldots, n
$$

where $\alpha_{i}$ is the intercept term, $\beta_{i}$ is the wealth coefficient, and $\pi_{i j}$ is the interest rate coefficient. The first part of Equation (6), $s_{i}=\alpha_{i}+\beta_{i} \log W$, is the wellknown Working (1943) Engel curve model of consumption theory. Equation (6) is also a version of the very popular almost ideal demand system of Deaton and Muellbauer's (1980), which has a number of desirable properties.

The coefficient $\beta_{i}$ represents 100 times the effect on the portfolio share of deposit $i, s_{i^{\prime}}$ of a $1 \%$ increase in wealth, with all interest rates remaining constant. The coefficient $\pi_{i j}$ measures the effect on $s_{i}$ of a one percentage point increase in the interest rate $r_{i^{\prime}}$ all other things being the same.

The balance sheet condition is given by $W=\sum_{i=1}^{n} a_{i}$ or $\sum_{i=1}^{n} s_{i}=1$. Using these conditions, we can derive the constraints on the parameters of the model. Summing Equation (6) over $i=1, \ldots, n$ and using the fact that the asset shares on the left-hand side of Equation (6) sums to one, we obtain

$$
1=\sum_{i=1}^{n} \alpha_{i}+\log W \sum_{i=1}^{n} \beta_{i}+\sum_{j=1}^{n}\left[\sum_{i=1}^{n} \pi_{i j}\right] r_{j}
$$

For the above equation to be true, the following restrictions on the coefficients $\alpha_{i}, \beta_{i}$, and $\pi_{i j}$ should hold:

$$
\sum_{i=1}^{n} \alpha_{i}=1, \quad \sum_{i=1}^{n} \beta_{i}=0, \quad \sum_{i=1}^{n} \pi_{i j}=0
$$

As discussed by Deaton and Muellbauer (1980) and Taylor and Clements (1983), the coefficients $\pi_{i j}$ in relation to the interest rates should satisfy the homogeneity restriction given by

$$
\sum_{j=1}^{n} \pi_{i j}=0, \quad i=1, \ldots, n
$$

and the Slutsky symmetry restriction given by

$$
\pi_{i j}=\pi_{j i}, \quad i, j=1, \ldots, n
$$


The homogeneity restriction of Equation (7) means that the demand functions of Equation (6) are homogeneous of degree zero. In other words, an equal percentage point change in total wealth $W$ and an equal percentage point change in the relative rates of returns leaves the share of each asset unchanged. The Slutsky symmetry of Equation (8) means that interest rate substitution effects are symmetric. A priori, one would expect the diagonal elements of the $\left[\pi_{i j}\right]$ matrix to be positive and the off-diagonal elements to be negative (positive), reflecting the substitutability (complementarity) between the assets.

The wealth and interest rate elasticities from Equation (6) for asset $i$ can be derived as

$$
\frac{\partial \log a_{i}}{\partial \log W}=1+\frac{\beta_{i}}{s_{i}}
$$

and

$$
\frac{\partial \log a_{i}}{\partial \log r_{j}}=r_{j} \frac{\pi_{i j}}{s_{i}}
$$

Equation (9) implies that if the coefficient $\beta_{i}$ is positive, then asset $i$ will have a wealth elasticity greater than 1 . On the other hand, if the coefficient $\beta_{i}$ is negative, then asset $i$ will have a wealth elasticity less than 1.

\section{B. Short-Run Error Correction Demand System}

Following Engle and Granger (1987), we propose the following short-run error correction demand system for asset $i$ as

$$
\Delta s_{i t}=\alpha_{i} \Delta s_{i t-1}+\beta_{i} \Delta \log W_{t}+\sum_{j=1}^{n} \pi_{i j} \Delta r_{j t}+\lambda_{i} E C_{i t-1}, \quad i=1, \ldots, n
$$

where the first difference series of a variable $x_{t}$ is defined as $\Delta x_{t}=x_{t}-x_{t-1}$ and $E C_{i t-1}$ is the error correction term calculated form the long-run demand system, the static almost demand system, given by Equation (6). The lagged dependent variable is incorporated into Equation (11) to take into account of the habit changes over time. A similar approach was taken by other researchers when analysing dynamic demand systems (see, for example, Karagiannis et. al, 2000, Li et. al. 2004, Nzuma and Sarker 2010). The error correction coefficient $\lambda_{i}$ which usually takes a value between 0 and -2 , is the rate of adjustment of the allocation share in relation to long-run Equation (6). The adding-up condition requires the coefficients $\alpha_{i}$ and $\lambda_{i}$ in Equation (11) to satisfy the condition that they are invariant with respect to $i$ (see, for example, Edgerton et al. 1996).

\section{DATA}

We use annual Indonesian data from 2002 to 2017 and consider three $(n=3)$ assets, namely, demand deposits $(i=1)$, saving deposits $(i=2)$, and time deposits $(i=3)$. The nominal values $\left(A_{i}, i=1,2,3\right)$ of demand deposits, saving deposits, and time 
deposit and the corresponding interest rates $\left(r_{i}, i=1,2,3\right)$ and the CPI are collected from the Bank of Indonesia official website. The real value $\left(a_{i}=A_{i} / C P I\right)$ of each financial asset is calculated as the nominal value $A_{i}$ deflated by the CPI. We define the real value of financial wealth as the sum of the holdings of the three assets, $W=\sum_{i=1}^{3} a_{i}$. The portfolio shares $s_{i^{\prime}} i=1,2,3$, are calculated as $s_{i}=a_{i} / W$.

Figure 1. Amount of Three Deposits, Indonesia, 2002-2017

This figure plots the demand deposit, saving deposit and time deposit in billions of rupiah in Indonesia during the period 20022017. The graph depicts the trend of the three deposits over the 16-year period.

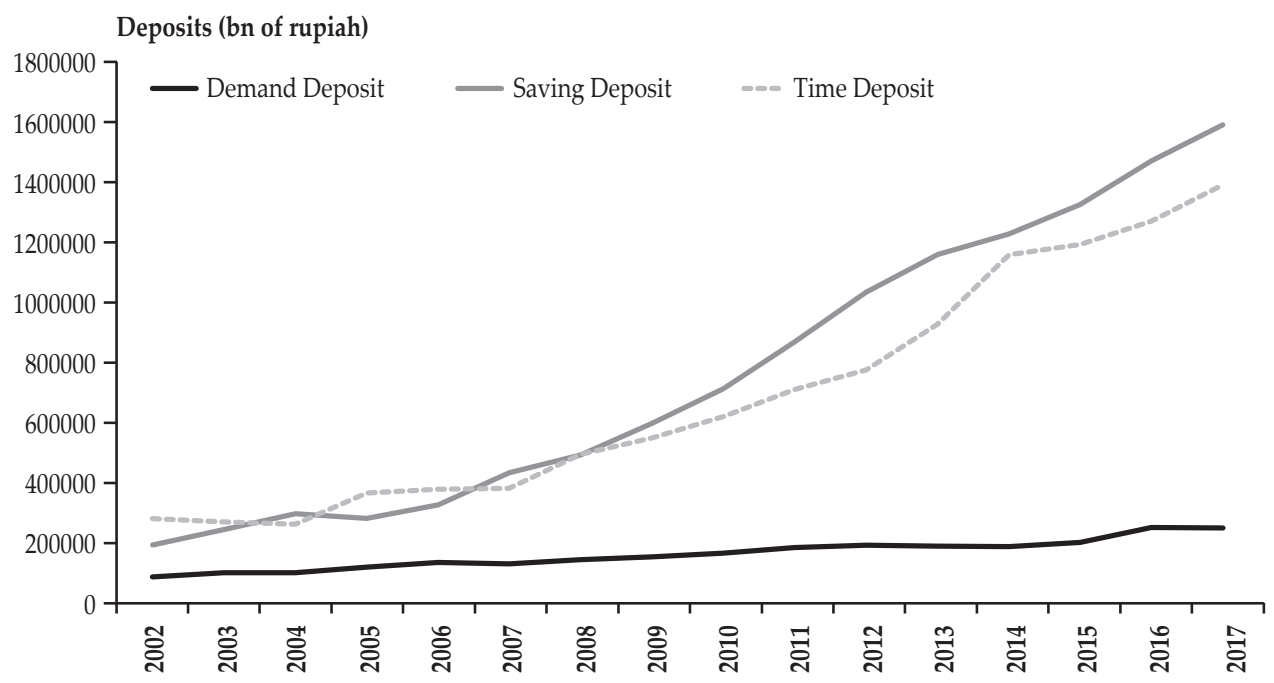

Figure 1 plots the real value of the three financial assets. As can be seen, saving and time deposits had experienced strong growth compared to demand deposits. Saving deposits appear to be the most popular form of bank investment among Indonesians. Figure 2 plots the portfolio shares of the three deposits. As can be seen, the saving deposit share has steadily increased at the expense of demand deposits and time deposits. During 202-2017, the demand deposit share fell from $15.3 \%$ to $7.7 \%$ and the time deposit share fell from $50.2 \%$ to $43.1 \%$, while the saving deposit share increased from $34.5 \%$ to $43.1 \%$. The average shares of demand deposits, saving deposits, and time deposits over the sample period 2002-2017 are $11.6 \%, 45.3 \%$, and $43.1 \%$, respectively. 


\section{Figure 2. Portfolio Shares of the Three Deposits (2002-2017)}

This figure plots the shares (in \%) of the demand deposit, saving deposit and time deposit in Indonesia over the period 2002-2017. The graph depicts how the portfolio shares of the three deposits have changed over the 16-year period.

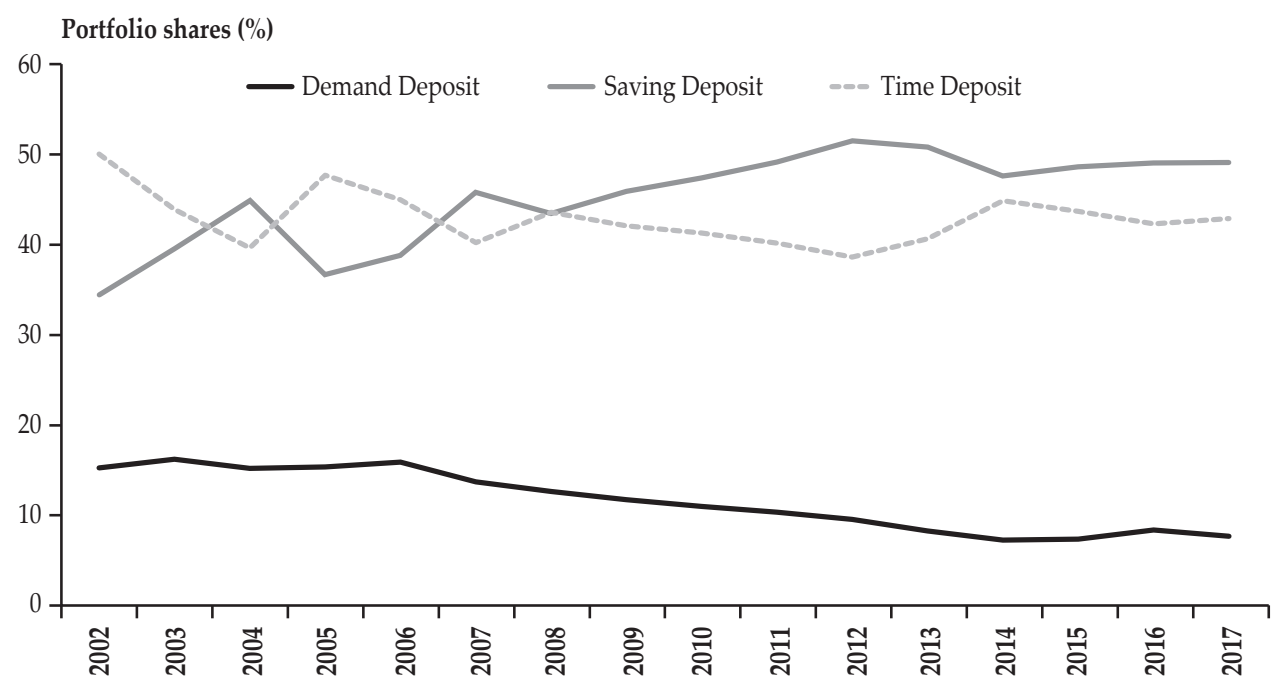

Figure 3 plots the portfolio share against $\log (W)$ for the three types of deposits. As can be seen, as the level of wealth increases, Indonesians tend to invest less in demand and saving deposits and increase their investment in time deposits. Even though such behaviour is expected, the interest rate could also play a major role, which could change this observation.

\section{Figure 3. Share of Deposits vs Logarithm of W (2002-2017)}

This figure plots the portfolio share of the three deposits, demand deposit, saving deposit and time deposit, against the logarithm of wealth in Indonesia over the period 2002-2017. The graphs depict the relationship between the three deposits and wealth in Indonesia over the 16-year period.

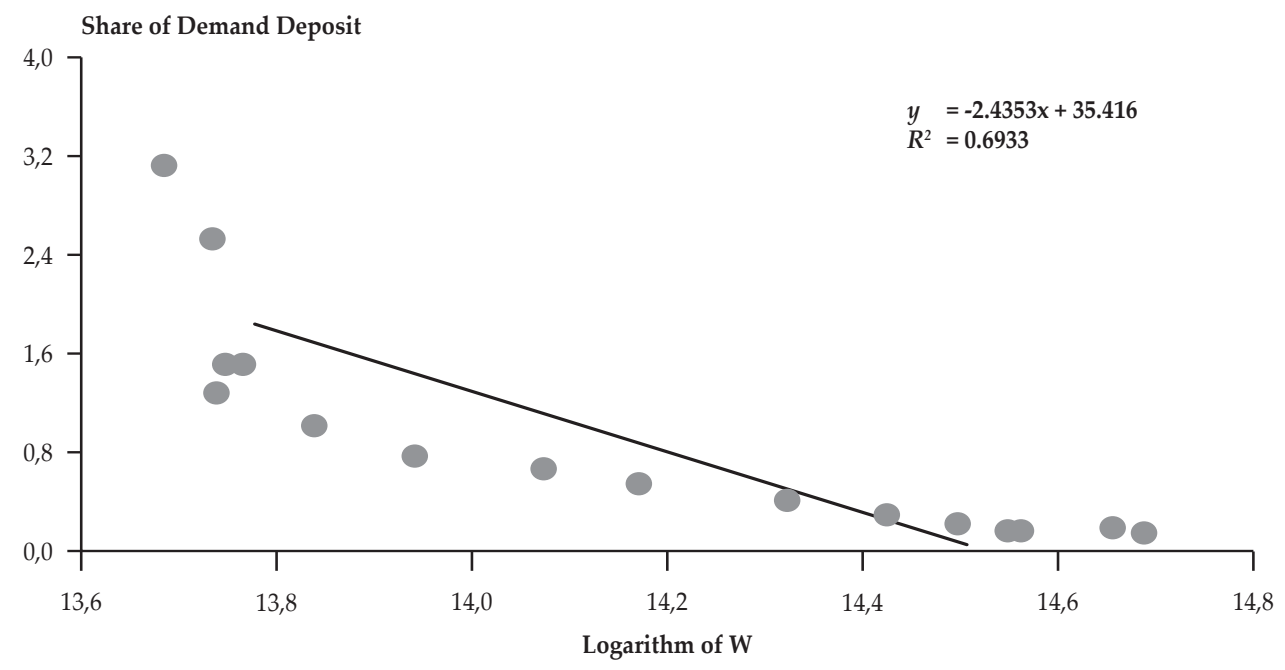


Figure 3: Share of deposits vs logarithm of $W$ (2002-2017) (Continued)
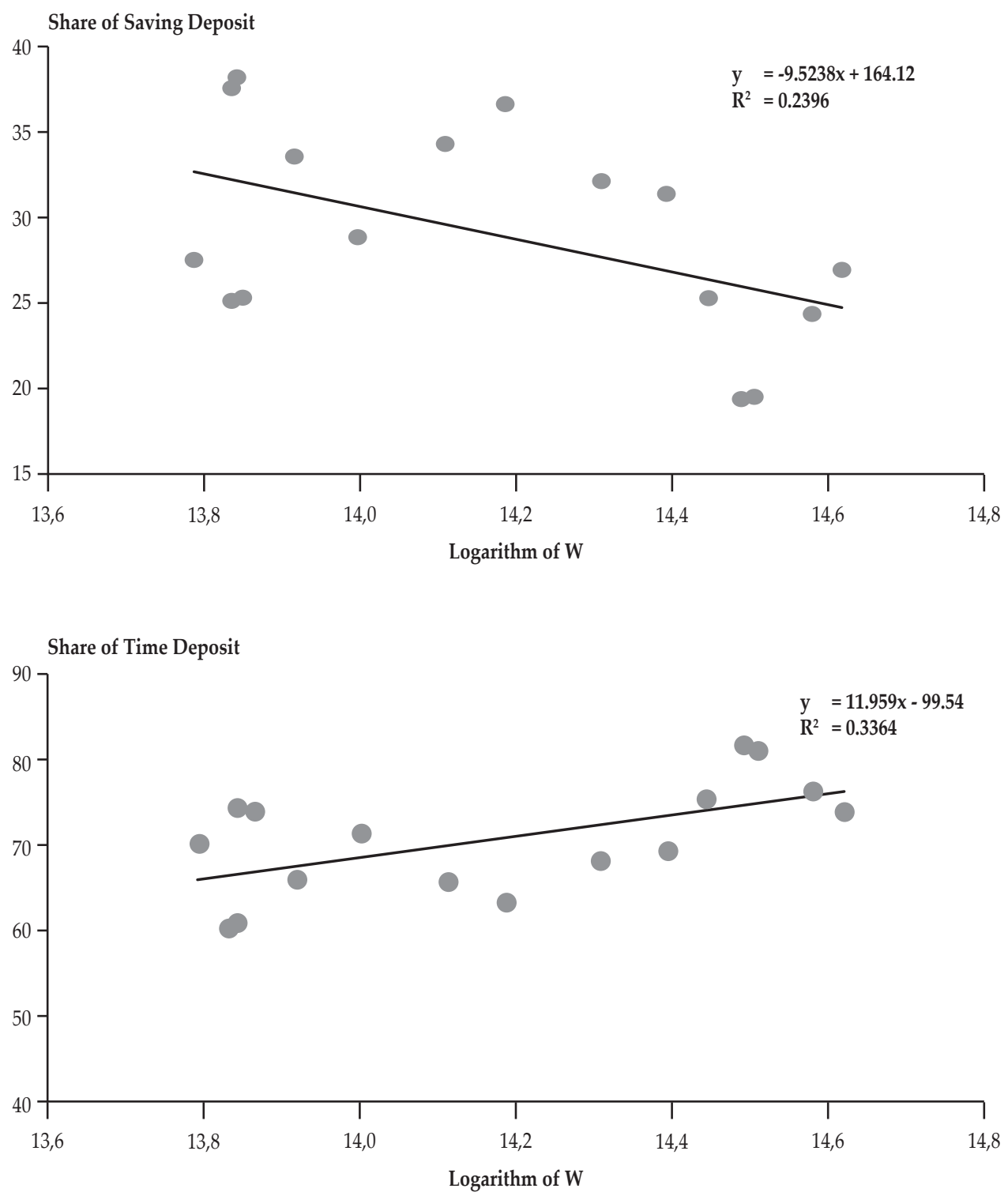

Figure 4 plots the share of each portfolio against the corresponding interest rate. As can be seen, all three shares are sensitive to the corresponding interest rate and the shares increase with increasing interest rates. A point worth noting is that the level of substitutability between the three portfolios is another factor to consider when we examine the relationship between portfolio share movements against interest rates. When we consider a system of portfolio models in the next section, these issues are addressed completely. 
Figure 4. Share of Deposits vs Interest Rates (2002-2017)

This figure plots the portfolio share of the three deposits, demand deposit, saving deposit and time deposit, against the interest rates in Indonesia over the period 2002-2017. The graphs depict the relationship between the three deposits and the corresponding interest rates in Indonesia over the 16-year period.

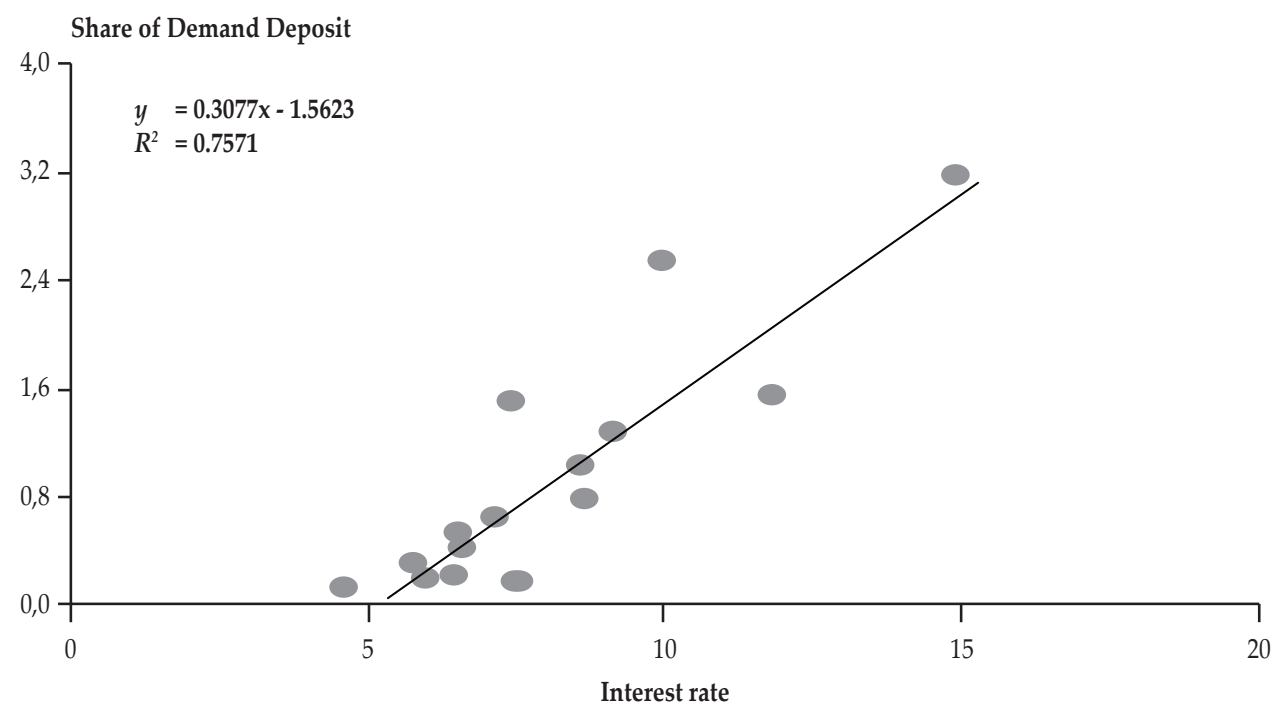

Share of Saving Deposit

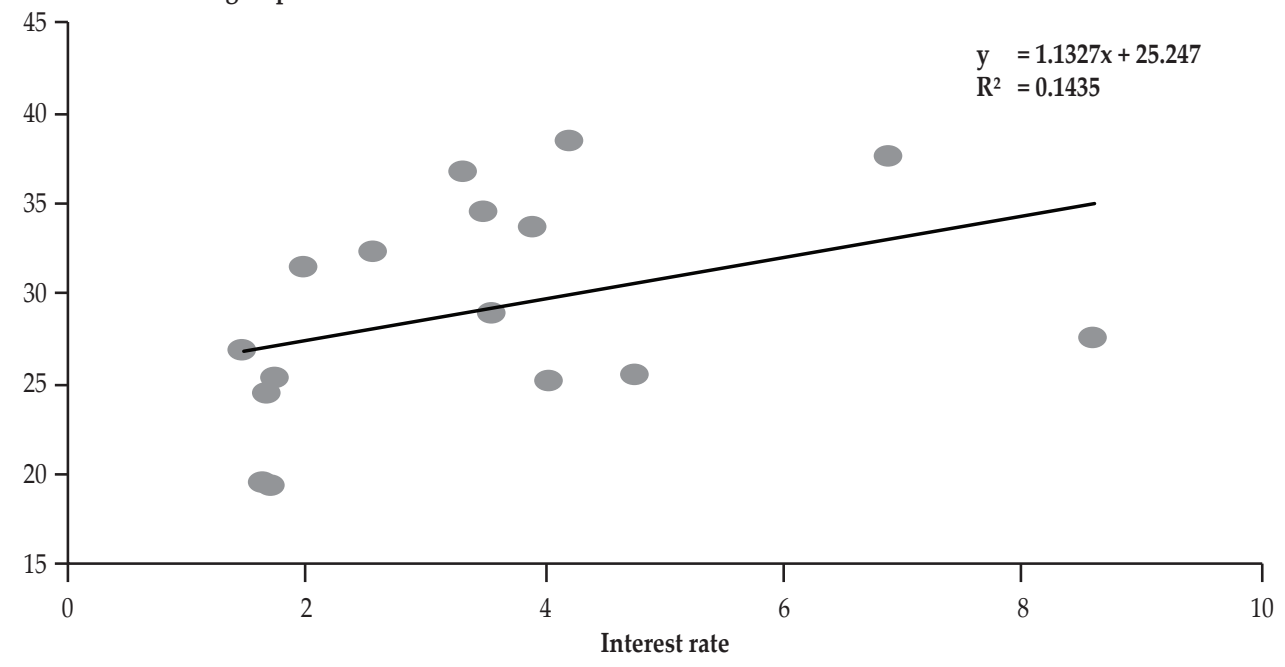


Figure 4. Share of Deposits vs Interest Rates (2002-2017) (Continued)

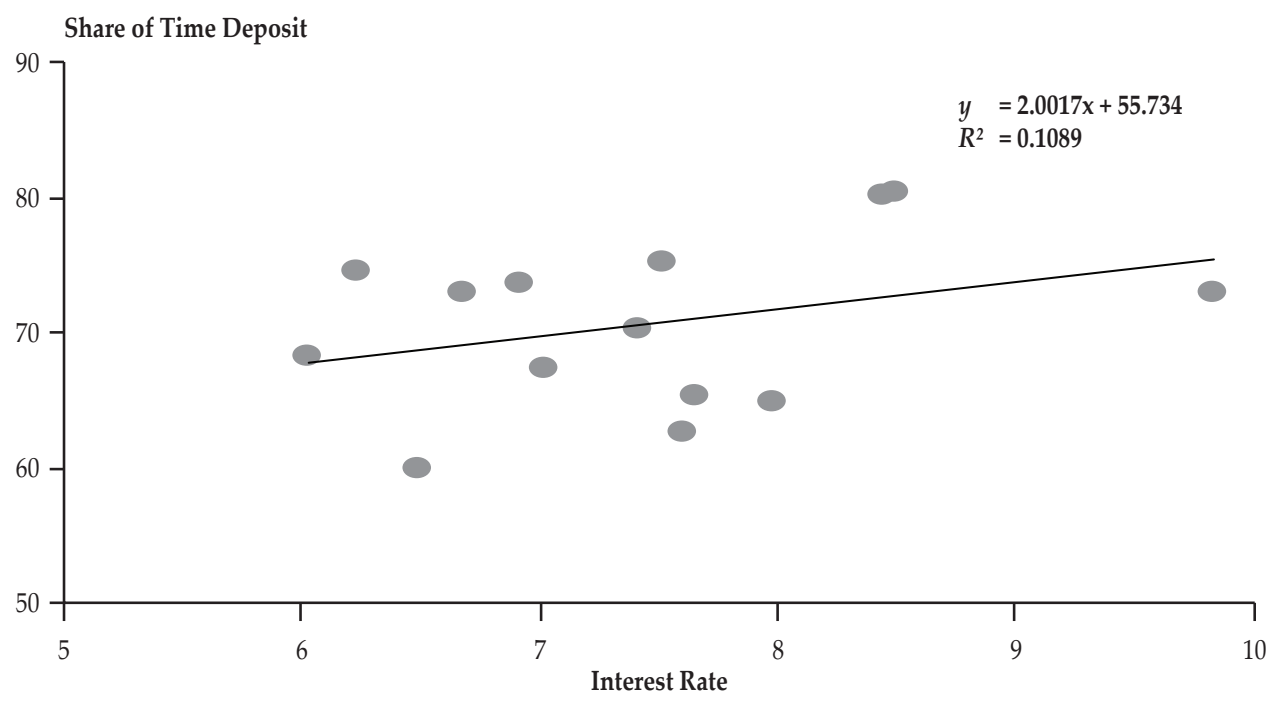

\section{ESTIMATION RESULTS}

We use annual Indonesian data from 2002 to 2017 and consider three $(n=3)$ assets, namely, demand deposits $(i=1)$, saving deposits $(i=2)$, and time deposits $(i=3)$. Below, we present the short-run and long-run estimation results and the implied wealth and interest rate elasticities.

\section{A. Long-run Results}

We estimate the long-run Equation (6) and present the estimation results in Tables 1 to 3 .

Table 1.

Parameter Estimates for Unrestricted Model

This table reports regression results of the unrestricted model given by Equation (6). The standard errors are given in parentheses. Symbol * indicates significance at the $5 \%$ level. All regressions include log of wealth and interest rates of the three deposits as exogenous variables. Coefficient of determination is also presented for the estimated equations.

\begin{tabular}{lcccccc}
\hline Deposit & $\begin{array}{c}\text { Intercept } \\
\text { term } \times \mathbf{1 0 0}\end{array}$ & $\ln W$ & $r_{1}$ & $r_{2}$ & $r_{3}$ & $\boldsymbol{R}^{2}$ \\
$\mathbf{( 1 )}$ & $\mathbf{( 2 )}$ & $\mathbf{( 3 )}$ & $\mathbf{( 4 )}$ & $\mathbf{( 5 )}$ & $\mathbf{( 6 )}$ & $\mathbf{( 7 )}$ \\
\hline$s_{1}$ & $142.447^{*}$ & $-9.201^{*}$ & -0.067 & 0.403 & -0.163 & 0.95 \\
& $(25.469)$ & $(1.804)$ & $(0.268)$ & $(0.385)$ & $(0.402)$ & \\
$s_{2}$ & -37.290 & 6.541 & -1.027 & -0.142 & -0.167 & 0.80 \\
& $(91.776)$ & $(6.499)$ & $(0.800)$ & $(1.152)$ & $(1.202)$ & \\
$s_{3}$ & -5.157 & 2.659 & 1.094 & -0.261 & 0.330 & \\
& $(85.318)$ & $(6.042)$ & $(0.744)$ & $(1.071)$ & $(1.118)$ & \\
\hline
\end{tabular}


Table 2.

\section{Parameter Estimates for Model with Homogeneity Imposed}

This table reports regression results of the homogeneity-imposed model. The standard errors are given in parentheses. Symbol * indicates significance at the $5 \%$ level. All regressions include log of wealth and interest rates of the three deposits as exogenous variables. Coefficient of determination is also presented for the estimated equations.

\begin{tabular}{lcccccc}
\hline Deposit & $\begin{array}{r}\text { lntercept } \\
\text { term } \times \mathbf{1 0 0}\end{array}$ & $\ln W$ & $r_{1}$ & $r_{2}$ & $r_{3}$ & $R^{2}$ \\
$\mathbf{( 1 )}$ & $\mathbf{( 2 )}$ & $\mathbf{( 3 )}$ & $\mathbf{( 4 )}$ & $\mathbf{( 5 )}$ & $\mathbf{( 6 )}$ & $\mathbf{( 7 )}$ \\
\hline$s_{1}$ & $162.61^{*}$ & $-10.607^{*}$ & -0.131 & 0.149 & -0.018 & 0.95 \\
& $(15.652)$ & $(1.138)$ & $(0.219)$ & $(0.196)$ & $(0.308)$ & \\
$s_{2}$ & $-193.92^{*}$ & $17.466^{*}$ & -0.530 & $1.825^{*}$ & -1.295 & 0.75 \\
& $(53.937)$ & $(3.921)$ & $(0.754)$ & $(0.676)$ & $(1.062)$ & \\
$s_{3}$ & 131.308 & -6.859 & 0.661 & -1.975 & 1.314 & \\
& $(56.162)$ & $(4.083)$ & $(0.785)$ & $(0.704)$ & $(1.106)$ & \\
\hline
\end{tabular}

Table 1 reports the unrestricted model parameter estimates. As can be seen, the wealth coefficient for demand deposits is negative (i.e. the wealth elasticity value is less than one) and statistically significant, whereas the wealth coefficients for saving deposits and time deposits are positive (i.e., the wealth elasticity value is greater than one) but statistically insignificant. Among the own interest rate coefficients, only the effect of own interest rate on time deposits is positive while other two demand deposit and saving deposit are negative. The negative sign is unexpected. However, none of the three own interest rate coefficient estimates are statistically significant. We test the null hypothesis of homogeneity given by Equation (7) and, since the value of the $\chi^{2}(1)$ test statistic is 6.58 with a $p$-value $=0.04$, we have support for the homogeneity hypothesis at the $1 \%$ of level of significance.

Table 2 presents the homogeneity-constrained estimates. When a homogeneity restriction is imposed with regard to the own interest rate coefficients, the coefficient corresponding to saving deposits changes to the correct positive sign and becomes statistically significant. Among the wealth coefficients, in addition to the demand deposit coefficient, the saving deposit coefficient becomes statistically significant. We also test the null hypothesis of Slutsky symmetry given by Equation (8), given homogeneity, and, since the value of the $\chi^{2}(1)$ test statistic is 0.74 with $p$-value $=0.39$, we have support for the symmetry hypothesis at the $5 \%$ of level of significance. 
Table 3.

Parameter Estimates for Model with Homogeneity and Symmetry Imposed

This table reports regression results of the homogeneity and symmetry-imposed model. The standard errors are given in parentheses. Symbol * indicates significance at the 5\% level. All regressions include log of wealth and interest rates of the three deposits as exogenous variables. Coefficient of determination is also presented for the estimated equations.

\begin{tabular}{lcccccc}
\hline Deposit & $\begin{array}{r}\text { Intercept } \\
\text { term } \times 100\end{array}$ & $\ln W$ & $r_{1}$ & $r_{2}$ & $r_{3}$ & $R^{2}$ \\
$\mathbf{( 1 )}$ & $\mathbf{( 2 )}$ & $\mathbf{( 3 )}$ & $\mathbf{( 4 )}$ & $\mathbf{( 5 )}$ & $\mathbf{( 6 )}$ & $\mathbf{( 7 )}$ \\
\hline$s_{1}$ & 0.000 & $1.065^{*}$ & $1.769^{*}$ & $0.797^{* *}$ & $-2.566^{*}$ & 0.60 \\
& & $(0.136)$ & $(0.410)$ & $(0.411)$ & $(0.581)$ & \\
$s_{2}$ & $-273.71^{*}$ & $23.153^{*}$ & & $2.020^{*}$ & $-2.817^{*}$ & 0.70 \\
& $(44.90)$ & $(3.319)$ & & $(0.718)$ & $(0.827)$ & \\
$s_{3}$ & $373.71^{*}$ & $-24.219^{*}$ & & & $5.384^{*}$ & \\
& $(44.901)$ & $(3.321)$ & & & $(1.011)$ & \\
\hline
\end{tabular}

Table 3 presents the homogeneity- and symmetry-constrained results with the intercept term for the demand deposit equation set to zero (we set this coefficient $\alpha_{1}$ to zero to obtain the correct sign for the demand deposit own interest rate coefficient). The results are mostly of the correct, expected signs and are statistically significant. All the wealth coefficients are statistically significant at the $5 \%$ level. The wealth coefficients for demand deposits and saving deposits are positive (i.e. the wealth elasticity is greater than one) and that for time deposits is negative (e.g., the wealth elasticity is less than one), all highly statistically significant. The own interest rate coefficients are positive, as expected, and statistically significant. All cross-interest rate coefficients are also statistically significant. The cross-interest rate coefficients for demand deposits and time deposits and for saving deposits and time deposits are negative, indicating that demand deposits and time deposits and saving deposit and time deposit are pairwise substitutes. The cross-interest rate coefficients for the demand deposits and saving deposits are positive, indicating that demand deposits and saving deposits are pairwise complements.

Table 4 presents the wealth and interest rate elasticities calculated based on Equations (9) and (10) and the sample mean shares $\bar{s}_{1}=11.64, \bar{s}_{2}=45.31$, and $\bar{s}_{3}=$ 43.05 , and interest rates $\bar{r}_{1}=8.04, \bar{r}_{2}=3.48$, and $\bar{r}_{3}=7.98$. As can be seen, the wealth elasticities for demand deposits and saving deposits are 1.09 and 1.51, respectively, and that for time deposit is 0.44 . The own interest rate elasticities for demand deposits, saving deposits, and time deposits are 1.22, 0.16 , and 1.00, respectively. The cross-interest rate elasticities for demand deposits and saving deposits, demand deposits and time deposits, saving deposits and demand deposits, saving deposits and time deposits, time deposits and demand deposits, and time deposits and saving deposits are $0.24,-1.76,0.14,-0.50,-0.48$, and -0.23 , respectively. 
Table 4.

\section{Implied Elasticities for Model with Homogeneity and Symmetry Imposed}

This table reports the wealth and interest rate elasticities obtained from Equations (9) and (10) at sample means and using the homogeneity and symmetry constrained estimates presented in Table 3 . The standard errors are given in parentheses.

\begin{tabular}{lcccc}
\hline $\begin{array}{l}\text { Deposit } \\
\mathbf{( 1 )}\end{array}$ & $\begin{array}{c}\text { Wealth } \\
\mathbf{( 2 )}\end{array}$ & $\begin{array}{c}\text { Demand } \\
\mathbf{( 3 )}\end{array}$ & $\begin{array}{c}\text { Saving } \\
\mathbf{( 4 )}\end{array}$ & $\begin{array}{c}\text { Time } \\
\mathbf{( 5 )}\end{array}$ \\
\hline Demand & 1.09 & 1.22 & 0.24 & -1.76 \\
& $(0.01)$ & $(0.28)$ & $(0.12)$ & $(0.40)$ \\
Saving & 1.51 & 0.14 & 0.16 & -0.50 \\
& $(0.07)$ & $(0.07)$ & $(0.06)$ & $(0.15)$ \\
Time & 0.44 & -0.48 & -0.23 & 1.00 \\
& $(0.08)$ & $(0.11)$ & $(0.07)$ & $(0.19)$ \\
\hline
\end{tabular}

\section{B. Short-run Results}

Before we estimate the short-run error correction model (11), we investigate the stationarity and cointegration relationship of the variables in the long-run model. Table 5 presents the Dickey-Fuller (1979) unit root test results and Table 6 presents the Engle-Granger (1987) cointegration test results. As can be seen, almost all the variables are I(1) and a cointegrating relationship exists between the variables in Equation (6). These results validate the estimation of Equation (11).

Table 5.

\section{Dickey-Fuller Unit Root Test Results}

This table reports the results for the Dickey-Fuller unit root test for the stationarity of the variables of the model in level form and first-differenced form, and the order of integration. The symbol * denotes statistical significance at the $1 \%$ level.

\begin{tabular}{lccccc}
\hline & \multicolumn{2}{c}{ Level Series } & \multicolumn{2}{c}{ First-Differenced Series } & Overall \\
Variable & $\boldsymbol{p}$-value & Conclusion & $p$-value & Conclusion & Conclusion \\
$\mathbf{( 1 )}$ & $\mathbf{( 2 )}$ & $\mathbf{( 3 )}$ & $\mathbf{( 4 )}$ & $\mathbf{( 5 )}$ & $\mathbf{( 6 )}$ \\
\hline$s_{1}$ & 0.67 & Non-stationary & 0.014 & Stationary & $\mathrm{I}(1)$ \\
$s_{2}$ & 0.15 & Non-stationary & 0.000 & Stationary & $\mathrm{I}(1)$ \\
$s_{3}$ & 0.04 & Non-stationary* & 0.000 & Stationary & $\mathrm{I}(1)^{*}$ \\
$\ln W$ & 0.09 & Non-stationary & 0.035 & Stationary & $\mathrm{I}(1)$ \\
$r_{1}$ & 0.02 & Non-stationary* & 0.009 & Stationary & $\mathrm{I}(1)^{*}$ \\
$r_{2}$ & 0.40 & Non-stationary & 0.030 & Stationary & $\mathrm{I}(1)$ \\
$r_{3}$ & 0.00 & Stationary & 0.000 & Stationary & $\mathrm{I}(0)$ \\
\hline
\end{tabular}

Table 6.

Results of Engle-Granger cointegration test results

This table reports the results of the Engle-Granger cointegration test for the model variables. In column (1), $e_{1}, e_{2}$ and $e_{3}$ denote the residuals of the estimated equations.

\begin{tabular}{lcc}
\hline Variable & $p$-value & Conclusion \\
$\mathbf{( 1 )}$ & $\mathbf{( 2 )}$ & $\mathbf{( 3 )}$ \\
\hline$e_{1}$ & 0.004 & $\mathrm{I}(0)$ \\
$e_{2}$ & 0.003 & $\mathrm{I}(0)$ \\
$e_{3}$ & 0.001 & $\mathrm{I}(0)$ \\
\hline
\end{tabular}


We now estimate Equation (11) and report the results in Tables 7 to 9, which present the unrestricted, homogeneity-imposed, and symmetry-imposed model estimates, respectively. As can be seen, the results improve when more and more theoretical restrictions are imposed. As before, we also test the homogeneity and symmetry hypotheses and find both to be supported by the data.

Table 7.

Parameter Estimates for Unrestricted Model

This table reports the regression results of the short-run unrestricted model given by Equation (11). The standard errors are given in parentheses.

\begin{tabular}{lcccccc}
\hline Deposit & $\Delta \boldsymbol{s}_{i, \mathrm{t}-\mathbf{1}}$ & $\Delta(\ln W)$ & $E C(-\mathbf{1})$ & $\Delta r_{1}$ & $\Delta r_{2}$ & $\Delta r_{3}$ \\
$\mathbf{( 1 )}$ & $\mathbf{( 2 )}$ & $\mathbf{( 3 )}$ & $\mathbf{( 4 )}$ & $\mathbf{( 5 )}$ & $\mathbf{( 6 )}$ & $\mathbf{( 7 )}$ \\
\hline$s_{1}$ & 0.740 & -1.062 & -1.108 & 0.299 & 0.621 & -0.327 \\
& $(0.130)$ & $(2.247)$ & $(0.155)$ & $(0.128)$ & $(0.230)$ & $(0.168)$ \\
$s_{2}$ & & 14.154 & -1.108 & -0.933 & 0.054 & -0.535 \\
& & $(8.915)$ & $(0.155)$ & $(0.482)$ & $(1.095)$ & $(0.773)$ \\
$s_{3}$ & 0.740 & -13.091 & -1.108 & 0.634 & -0.675 & 0.862 \\
& $(0.130)$ & $(9.194)$ & $(0.155)$ & $(0.498)$ & $(1.119)$ & $(0.791)$ \\
\hline
\end{tabular}

Table 8.

Parameter Estimates for Model with Homogeneity Imposed

This table reports the regression results of the short-run homogeneity constrained version of model (11). The standard errors are given in parentheses.

\begin{tabular}{lcccccc}
\hline Deposit & $\Delta(\mathbf{l n} W D)$ & $\Delta(\ln W)$ & $E C(-1)$ & $\Delta r_{1}$ & $\Delta r_{2}$ & $\Delta r_{3}$ \\
$\mathbf{( 1 )}$ & $\mathbf{( 2 )}$ & $\mathbf{( 3 )}$ & $\mathbf{( 4 )}$ & $\mathbf{( 5 )}$ & $\mathbf{( 6 )}$ & $\mathbf{( 7 )}$ \\
\hline$s_{1}$ & 0.684 & -5.283 & -1.214 & 0.124 & -0.138 & 0.015 \\
& $(0.154)$ & $(2.634)$ & $(0.175)$ & $(0.155)$ & $(0.153)$ & $(0.218)$ \\
$s_{2}$ & & 23.181 & -1.214 & -0.845 & 2.186 & -1.341 \\
& & $(9.157)$ & $(0.175)$ & $(0.523)$ & $(0.520)$ & $(0.737)$ \\
$s_{3}$ & 0.684 & -17.898 & -1.214 & 0.721 & -2.048 & 1.326 \\
& $(0.154)$ & $(9.528)$ & $(0.175)$ & $(0.545)$ & $(0.542)$ & $(0.769)$ \\
\hline
\end{tabular}

Table 9.

Parameter Estimates for Model with Homogeneity and Symmetry Imposed

This table reports the regression results of the short-run homogeneity and symmetry constrained version of model (11). The standard errors are given in parentheses. The symbol * denotes non-stationarity at the $5 \%$ level.

\begin{tabular}{lcccccc}
\hline Deposit & $\Delta(\mathbf{l n} W D)$ & $\Delta(\mathbf{l n} W)$ & $E C(-\mathbf{1})$ & $\Delta r_{1}$ & $\Delta r_{2}$ & $\Delta r_{3}$ \\
$\mathbf{( 1 )}$ & $\mathbf{( 2 )}$ & $\mathbf{( 3 )}$ & $\mathbf{( 4 )}$ & $\mathbf{( 5 )}$ & $\mathbf{( 6 )}$ & $\mathbf{( 7 )}$ \\
\hline$s_{1}$ & 0.719 & $-5.636^{*}$ & $-1.196^{*}$ & 0.029 & -0.222 & 0.193 \\
& $(0.197)$ & $(3.231)$ & $(0.207)$ & $(0.177)$ & $(0.177)$ & $(0.250)$ \\
$s_{2}$ & & $26.960^{*}$ & $-1.196^{*}$ & & $2.323^{*}$ & $-2.101^{*}$ \\
& & $(8.688)$ & $(0.207)$ & & $(0.515)$ & $(0.545)$ \\
$s_{3}$ & 0.719 & $-21.324^{*}$ & $-1.196^{*}$ & & & $1.908^{*}$ \\
& $(0.197)$ & $(9.269)$ & $(0.207)$ & & & $(0.600)$ \\
\hline
\end{tabular}


Table 9 presents the homogeneity- and symmetry-constrained results but suppressing the lagged share term for the saving deposit equation (we set this coefficient to zero in order to obtain the correct sign for the own interest rate coefficient for saving deposits). As can be seen, the estimates presented in Table 9 are mostly of the expected signs and are statistically significant. The estimated parameter of the lagged share, $\alpha$, is statistically significant meaning that one of the factors that plays a major role is habit persistence. The error correction coefficient $\lambda$ is statistically significant, and in the usual range of -2 to 0 , meaning that any short-run movement away from the long-run equilibrium will be assumed to be corrected and the system will be brought back towards the equilibrium path. The magnitude of $\lambda$ is slightly above unity, indicating that the convergence would be oscillating instead of a standard, monotonic convergence (when the error correction coefficient is between -1 and 0 ) to the equilibrium path directly. In this case, the error correction process is expected to fluctuate around the long-run value in a dampening manner and, once this process is complete, convergence to the equilibrium path is expected to accelerate. This situation has been reported by a number of studies (e.g. Narayan and Smyth, 2005).

All the short-run wealth coefficients are statistically significant at the $5 \%$ level. The wealth coefficient for saving deposits is positive (i.e. the short-run wealth elasticity is greater than one) and those for demand deposits and time deposits are negative (i.e., the short-run wealth elasticity is less than one). The own interest rate coefficients are positive, as expected, and are statistically significant for saving and time deposits. Among the cross-interest rate coefficients, that for the saving deposits-time deposits pair is negative and statistically significant, indicating pairwise substitution. The other two cross-interest rate coefficients for the demand deposits-saving deposits and demand deposits-time deposits pairs are not statistically significant.

Table 10 presents the implied short-run wealth and interest rate elasticities calculated based on Equations (9) and (10) and the sample mean shares $\bar{s}_{1}=11.64$, $\bar{s}_{2}=45.31$, and $\bar{s}_{3}=43.05$ and interest rates $\bar{r}_{1}=8.04, \bar{r}_{2}=3.48$, and $\bar{r}_{3}=7.98$. As can be seen, the short-run wealth elasticity for saving deposits is 1.60 and the wealth elasticities for demand deposits and time deposits are 0.52 and 0.50 , respectively. The own interest rate short-run elasticities for demand deposits, saving deposits, and time deposits are $0.02,0.18$, and 0.35 , respectively.

Table 10.

\section{Implied Elasticities for Model with Homogeneity and Symmetry Imposed}

This table reports the corresponding short-run wealth and interest rate elasticities obtained from Equations (9) and (10) at sample means and using the homogeneity and symmetry constrained estimates presented in Table 9 . The standard errors are given in parentheses.

\begin{tabular}{|c|c|c|c|c|}
\hline $\begin{array}{l}\text { Country } \\
\text { (1) }\end{array}$ & $\begin{array}{c}\text { Wealth } \\
\text { (3) }\end{array}$ & $\begin{array}{l}\text { Demand } \\
\text { (4) }\end{array}$ & $\begin{array}{c}\text { Saving } \\
\text { (5) }\end{array}$ & $\begin{array}{c}\text { Time } \\
\text { (6) }\end{array}$ \\
\hline Demand & $\begin{array}{c}0.52 \\
(0.28)\end{array}$ & $\begin{array}{c}0.02 \\
(0.12)\end{array}$ & $\begin{array}{l}-0.07 \\
(0.05)\end{array}$ & $\begin{array}{c}0.13 \\
(0.17)\end{array}$ \\
\hline Saving & $\begin{array}{l}1.60 \\
(0.19)\end{array}$ & $\begin{array}{l}-0.04 \\
(0.01)\end{array}$ & $\begin{array}{l}0.18 \\
(0.04)\end{array}$ & $\begin{array}{l}-0.37 \\
(0.10)\end{array}$ \\
\hline Time & $\begin{array}{r}0.50 \\
(0.22) \\
\end{array}$ & $\begin{array}{c}0.04 \\
(0.05) \\
\end{array}$ & $\begin{array}{l}-0.17 \\
(0.04) \\
\end{array}$ & $\begin{array}{c}0.35 \\
(0.11) \\
\end{array}$ \\
\hline
\end{tabular}


A comparison between the short- and long-run elasticities reveals that the wealth elasticities are about the same for saving deposits and time deposits but varies from 0.52 (short run) to 1.09 (long run) for demand deposits. The own interest elasticity is about the same in the short run and the long run for saving deposits but different for the other two assets.

\section{CONCLUSIONS}

In this paper, we analyse the patterns of demand for three financial assets in Indonesia, namely, demand deposits, saving deposit, and time deposits during 2002-2017. We used a system-wide approach to consumption economics and Deaton and Muellbauer's (1980) almost ideal demand system. We test the demand theory hypotheses of demand homogeneity and Slutsky symmetry and find that the two hypotheses are generally acceptable.

The results reveal that, generally, the wealth elasticity for saving deposits is larger than one and that for time deposits is less than one, whereas that for demand deposits varies from 0.5 (short run) to 1.1 (long run). The own interest rate coefficients are positive, as expected, and statistically significant. The own-interest rate elasticities for demand deposits, saving deposits, and time deposits in the short (long) run are $0.02(1.22), 0.18(0.16)$, and $0.35(1.00)$, respectively. In the long run, the three assets in the demand deposits-time deposits and saving depositstime deposits pairs are pairwise substitutes, whereas the assets in the demand deposits-saving deposits pair are pairwise complements. The elasticity estimates of this study can be used for macroeconomic policy making in the government and the banking industry.

Acknowledgement: The authors would like to thank the anonymous referees of this journal for their constructive comments which have helped improve the paper.

\section{REFERENCES}

Arrondel, L., Bartiloro, L., Fessler, P., Haliassos, M., Lindner, P., Mathä, T.Y., Rampazzi, C., Savignac, F., Schmidt, T., Schürz, M., and Vermeulen, P. (2013). How Do Households Choose to Allocate their Wealth? Some Stylized Facts Derived from the Eurosystem Household Finance and Consumption Survey. ECB Working Paper, No. 1722, ISBN 978-92-899-1130-6, European Central Bank (ECB), Frankfurt.

Brainard, W.C., and Tobin, J. (1968). Pitfalls in Financial Modelling. American Economic Review, 58, 99-122.

Becker, G., and Dimpfl, T. (2016). Labor Income Risk and the Reluctance of Household to Invest in Risky Financial Assets: A Panel Data Analysis. Studies in Economics and Finance, 33, 262-280.

Callen, T., and Thimann, C. (1997). Empirical Determinants of Household Saving - Evidence from OECD Countries. IMF Working Paper 97/181, International Monetary Fund. 
Carroll, C.D., Otsuka, M., and Slacalek, J. (2011). How Large are Housing and Financial Wealth Effects? A New Approac. Journal of Money, Credit and Banking, 43, 55-79.

Dalal, A.J. (1983). Comparative Statistics and Asset Substitutability/ Complementarity in a Portfolio Model: A Dual Approach. Review of Economic Studies, 50, 355-367.

Deaton, A., and Muellbauer, J. (1980). An Almost Ideal Demand System. American Economic Review, 70, 312-326.

Dickey, D.A., and Fuller, W.A. (1979). Distribution of the Estimators for Autoregressive Time Series with a Unit Root. Journal of American Statistical Association, 74, 427-431.

Edgerton, D. L., Assarsson, B., Hummelmose, A., Laurila, I. P., Rickertsen, K., and Vale, P. H. (1996). The Econometrics of Demand Systems: With Applications to Food Demand in the Nordic Countries. Springer Science \& Business Media, 34.

Engle, R. F., and Granger, C. W. (1987). Co-Integration and Error Correction: Representation, Estimation, and Testing. Econometrica 55, 251-276.

Heykal, M., Siagian, P., and Iswandi. (2014). Impact Analysis of Indonesian Financial Accounting Standard Based on the IFRS Implementation for Financial Instruments in the Indonesian Commercial Bank. Procedia Social and Behavioural Sciences, 109, 1247-1250.

Jha, S. (2015). Financial Asset Holdings and Political Attitudes: Evidence from Revolutionary England. Quarterly Journal of Economic, 103, 1485-1545.

Juster, F.T., Lupton, J.P., Smith, J.P., and Stafford, F. (2006). The Decline in Household Saving and The Wealth Effect. Review of Economics and Statistics, 88, 20-27.

Karagiannis, G., Katranidis, S., and Velentzas, K. (2000). An Error Correction Almost Ideal Demand System for Meat in Greece. Agricultural Economics, 22, 29-35.

Kukk, M. (2014). Distinguishing the Components of Household Financial Wealth: the Impact of Liabilities on Assets in Euro Area Countries. Proceedings of International Academic Conferences 0100418, International Institute of Social and Economic Sciences and Bank of Estonia Working Paper, 2, Estonia.

Li, G., Song, H., and Witt, S. F. (2004). Modelling Tourism Demand: A Dynamic Linear AIDS Approach. Journal of Travel Research, 43, 141-150.

Motley, B. (1970). Household Demand for Assets: A Model of Short-run Adjustments. The Review of Economics and Statistics, 52, 236-241.

Narayan, P.K., Narayan, S., and Mishra, V. (2009). Estimating Money Demand Functions for South Asian Countries. Empirical Economics, 36, 685-606.

Narayan, P.K., and Smyth, R. (2005). What Determines Migration Flows from Low-Income to High-Income Countries? An Empirical Investigation of Fiji-US. Migration 1972-2001. Contemporary Economic Policy, 24, 332-342.

Nzuma, J. M., and Sarker, R. (2010). An Error Corrected Almost Ideal Demand System for Major Cereals in Kenya. Agricultural Economics, 41, 43-50.

Taylor, J.C., and Clements, K.W. (1983). A Simple Portfolio Allocation Model of Financial Wealth. European Economic Review, 23, 241-251. 
This page is intentionally left blank 